\title{
ON MATHEMATICAL MODELING OF THE MEASUREMENT TRANSDUCERS
}

Yu. V. Khudyakov, South Ural State University, Chelyabinsk, Russian Federation, hudyakov74@gmail.com

The article presents a generalized mathematical model of the measurement transducer, which is based on a system of Leontiev type, that is a degenerate system of linear ordinary differential equations. We consider examples of the theory of descriptor systems, which show that the Leontiev type system is a part of models, which are also studied by the automatic control theory. Unlike previously studied mathematical models of the measurement transducer, an additional term is introduced in the system of algebraic equations of its generalized model. This term is necessary in order to consider not only the inertial of measurement transducer, but also the noises. We present the diagrams of different measurement transducers, such that their mathematical description leads to the construction of a generalized mathematical model of the measurement transducer.

Keywords: Leontief type system, dynamic measurements, descriptor systems, the theory of optimal measurement, the measurement transducer.

\section{Introduction}

In dynamic measurement theory there are two approaches to the solution of the problem of dynamically distorted signal recovering. In the first case, the dynamic characteristics to choose measurement instruments and the estimate of measurement error in order to determine their impact on the signal distortion are determined and the questions of the control of dynamic systems are resolved. In the second case, one reduces the difference between output signals of the model and the sensor by changing of the structure of the measurement transducer model (MT) or by application of various modes of its studies, and then determines the value of the model input signal, which is closed to the value of the sensor input signal.

For the first time A. L. Shestakov [1] proposed to consider the following system as MT dynamic model to solve the problem of dynamically distorted signal recovering in measurement systems:

$$
\left\{\begin{array}{l}
\dot{x}=A x+B u, \\
y=C x
\end{array}\right.
$$

where $x=\operatorname{col}\left(x_{1}, \ldots, x_{n}\right)$ and $\dot{x}=\operatorname{col}\left(\dot{x}_{1}, \ldots, \dot{x}_{n}\right)$ are vector functions of state and velocity of MT state change, respectively, and $x(0)=\operatorname{col}(0, \ldots, 0) ; u=\operatorname{col}\left(u_{1}, \ldots, u_{m}\right)$ and $y=\operatorname{col}\left(y_{1}, \ldots, y_{l}\right)$ are vector functions of input (measured) and output (observed) signals, respectively; matrices of MT $A$, sensor $B$ and output $C$ are $[n \times n],[n \times m]$ and $[l \times n]$ matrices, respectively.

E.I. Nazarova [2] consider system (1) as a model of Leontief type

$$
L \dot{z}=M z+D u,
$$

where $z=\left(x_{1}, \ldots, x_{n}, y_{1}, \ldots, y_{l}\right), u=\left(u_{1}, \ldots, u_{m}, 0, \ldots, 0\right)$, matrices $L, M$ and $D$ are constructed by $A, B$ and $C$. Note that (2) is a special, finite-dimensional case of 
the inhomogeneous linear equation of Sobolev type. Therefore the research of both MT mathematical model and the problem of optimal measurement with regard to MT inertial is based on the methods of the degenerate (semi) groups theory, which was proposed by G. A. Sviridyuk and his students [3].

In $[4,5]$ A. L. Shestakov and G. A. Sviridyuk proposed the mathematical model of the measurement transducer (MT). One of the components of this model is the system of Leontief type equations

$$
L \dot{x}=M x+D u,
$$

where square matrices $L$ and $M$ model the MT structure, and $L$ is not assumed to be reversible, vector function $x=x(t)$ is the state of MT, and vector function $u=u(t)$ is an input signal. The system of differential equations (1) is complemented by the algebraic system

$$
y=C x,
$$

where vector function $y=y(t)$ models a signal at the output of MT, and, in general case, the matrices $D$ and $C$ are square.

The purpose of this article is representation of generalized mathematical model of the measurement transducer, its qualitative study.

\section{Differential-Algebraic and Descriptor System in Control Theory}

Mathematical models of different systems - technical, physical, chemical and biological - often include both differential and algebraic relations and restrictions. There is no common term for such systems. Both foreign and russian researchers use the following terms: algebraic-differential system, differential-algebraic system, singular system, Leontief type system, implicit system, descriptor system (the detailed overview is presented in [6]). Usually, the term "differential-algebraic equations (system)" is used for their abstract research, and the term "descriptor system"is used for research of mathematical models of special processes and systems, for example, for research of automatic control theory questions. Note that this statement is the result of a subjective analysis of literature by the authors. It is possible that researchers use a special term for other reasons.

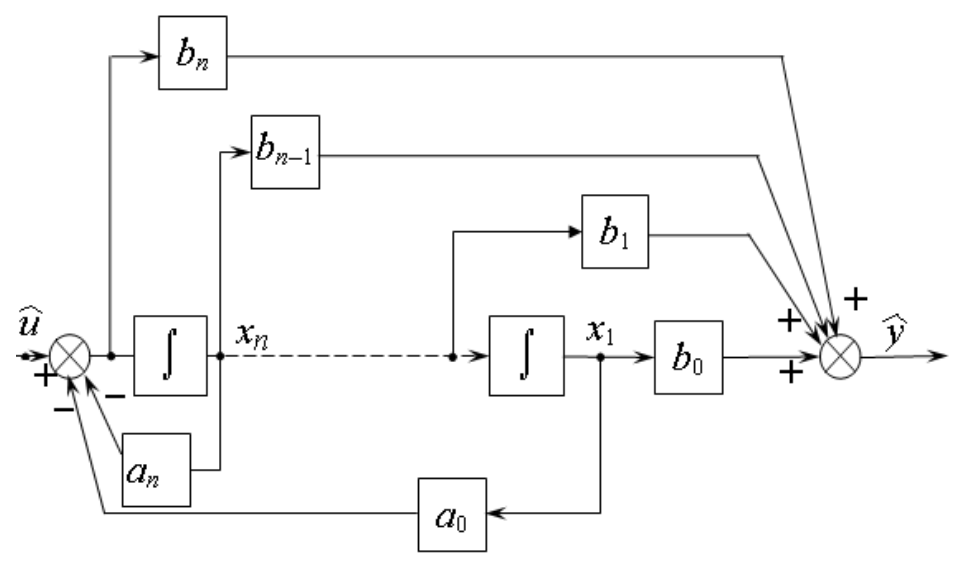

Fig. 1. Block diagram of the measurement transformer 
However, the stationary linear system

$$
\left\{\begin{aligned}
E \dot{x}(t) & =A x(t)+B u(t), \\
y(t) & =C x(t)+D u(t),
\end{aligned}\right.
$$

where matrix $E$ can be both degenerate and non-degenerate (i.e. $\operatorname{rank}(E) \leq n$ ), is called both differential-algebraic and descriptor systems.

Earlier in the automatic control theory, the theory of dynamic measurement, most systems were considered in the case, when $\operatorname{rank}(E)=n$. Let us consider an example of modelling of the measurement transformer, which block diagram is shown in Fig. 1.

Mathematical model of the measurement transformer is a differential-algebraic (descriptor) system

$$
\left\{\begin{array}{l}
\dot{x}_{1}=x_{2}, \\
\dot{x}_{2}=x_{3}, \\
\cdots, \\
\dot{x}_{n}=\frac{1}{a_{n}} \hat{u}-\frac{a_{0}}{a_{n}} x_{1}-\frac{a_{1}}{a_{n}} x_{2}-\cdots-\frac{a_{n-1}}{a_{n}} x_{n-1}, \\
\hat{y}=b_{0} x_{1}+b_{1} x_{2}+\cdots+b_{n-1} x_{n}+b_{n} x_{n} .
\end{array}\right.
$$

In $[4,5]$ the system of the form (3) was proposed as a mathematical model of the measurement transducer. At the same time, the following question remained open. In which cases the system (3) should be used as a mathematical model, and in which cases the system (5) is sufficient. We answer this question in the next section.

\section{Generalized Mathematical Model of Measurement Transducer}

We give an example before construction of a generalized model of the measurement transducer.

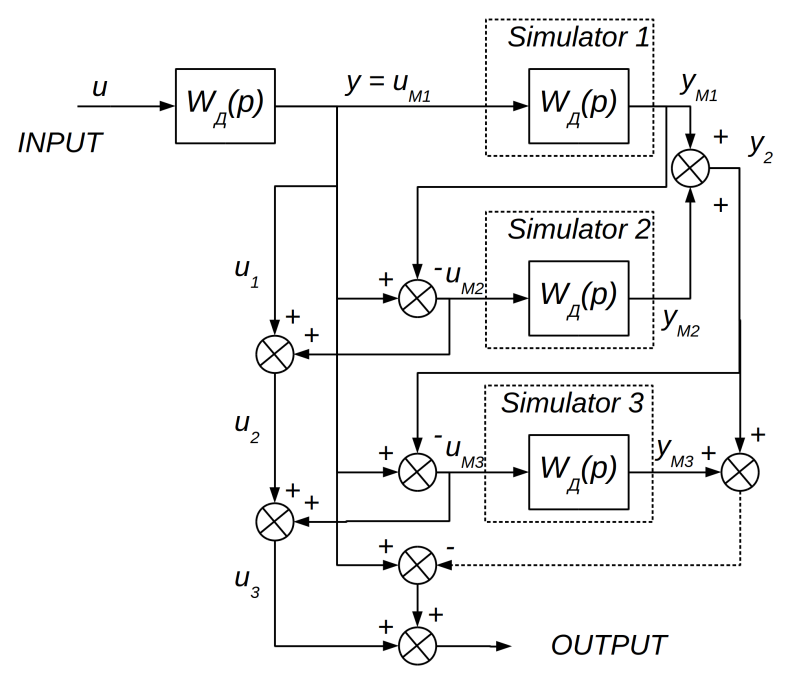

Fig. 2. Block diagram of the iterative measurement transducer

Consider the model of the measurement transducer using an iterative principle to restore the dynamically distorted signal, that allows to achieve high dynamic accuracy 
of the dynamic measurements. Block diagram of the iterative measurement transducer is shown in Fig. 2. Mathematical model of the iterative measurement transducer is presented by the system

$$
\left\{\begin{array}{l}
\dot{x}_{M_{1}}=A x_{M_{1}}+B u_{M_{1}} \\
y_{M_{1}}=C x_{M_{1}} \\
u_{M_{2}}=u_{M_{1}}-y_{M_{1}} \\
\dot{x}_{M_{2}}=A x_{M_{2}}+B u_{M_{2}} \\
y_{M_{2}}=C x_{M_{2}} \\
u_{M_{3}}=u_{M_{1}}-y_{M_{2}} \\
\dot{x}_{M_{3}}=A x_{M_{3}}+B u_{M_{3}} \\
y_{M_{3}}=C x_{M_{3}} \\
u_{M_{4}}=u_{M_{1}}-y_{M_{3}} \\
\ldots \\
\dot{x}_{M_{n}}=A x_{M_{n}}+B_{M_{n}} u_{M_{n}} \\
y_{M_{n}}=C x_{M_{n}} \\
u_{M_{n+1}}=u_{M_{1}}-y_{M_{n}} \\
y=u_{M_{1}}+u_{M_{2}}+u_{M_{3}}+u_{M_{4}}+\ldots+u_{M_{n+1}}
\end{array}\right.
$$

The form of system (6) reflects an idea of dynamic error correction for the iterative principle, which consists in the sequential use of an arbitrary number of measurement transformers. The output of the system is a sum of the observed signal and the errors, which are modeled by iterations. A mathematical model of each of the measurement transformers is presented by system

$$
\left\{\begin{array}{l}
\dot{x}_{M_{i}}=A x_{M_{i}}+B u_{M_{i}}, \\
y_{M_{i}}=C x_{M_{i}} .
\end{array}\right.
$$

The input of an arbitrary measurement transformer $u_{M_{i+1}}=u_{M_{1}}-y_{M_{i}}, i=2,3 \ldots n$ is an error revealed by the previous iteration.

In [7] A. L. Shestakov proposed a measurement transducer with an iterative principle of signal recovery and determined a required number $n$ of measurement transformers to get zero steady error. Mathematical model of the measurement transducer can be presented by system

$$
\left\{\begin{aligned}
L \dot{z}(t) & =M z(t)+G u(t), \\
w & =P z(t)+Q u(t),
\end{aligned}\right.
$$

where $z=\operatorname{col}\left(x_{M_{1}}, \ldots, x_{M_{n}}, y_{M_{1}}, \ldots, y_{M_{n}}, u_{M_{2}}, \ldots, u_{M_{n+1}}\right), u=\operatorname{col}\left(u_{M_{1}}, 0, \ldots, 0\right)$.

Generalized mathematical model of the measurement transducer is represented in the form (8). That is it combines several subsystems,each of which is a model of one measurement transformer. Differential equations in the system represent a set of dynamic elements of the system (subsystems), and algebraic equations - the connections between dynamic elements. This approach allows: 1) to model difficult measurement transducers with different types of connections between the measurement transformers by considering of different feedback types; 2) to solve not only the problems of recovering of dynamically distorted signals, but also the problems of restoring of the system states. 


\section{References}

1. Shestakov, A.L. The methods of theory of automatic control in dynamic measurements. Chelyabinsk, SUSU Publisher, 2013. (in Russian)

2. Keller A.V., Nazarova E.I. The Regularization Property and the Computational Solution of the Dynamic Measure Problem. Bulletin of the South Ural State University. Series Mathematical Modelling, Programming and Computer Software, 2010, no. 16 (195), issue 5, pp. 32-38. (in Russian)

3. Sviridyuk G.A. The Cauchy problem for a linear singular equation of Sobolev type. Differential equations. 1987, issue 23, no. 12, pp. 2169. (in Russian)

4. Shestakov A.L., Sviridyuk G.A. Optimal Measurement of Dynamically Distorted Signals. Bulletin of the South Ural State University. Series Mathematical Modelling, Programming and Computer Software. 2011, no. 17 (234), pp. 70-75.

5. Shestakov A.L., Sviridyuk G.A. A New Approach to Measurement of Dynamically Perturbed Signal. Bulletin of the South Ural State University. Series Mathematical Modelling, Programming and Computer Software, 2010, no. 16 (192), issue 5, pp. 116-120.

6. Belov A.A., Kurdyukov A.P. Descriptor system and control problems. Moscow, FIZMATLIT, 2015. (in Russian)

7. Shestakov A.L. Measurement transformer of dynamic parameters with the iterative principle of signal recovering. Instruments and systems. Control, monitoring, diagnostics, 1992, no. 10, pp. 23. (in Russian)

Yurii V. Khudyakov, PhD student, Department of equations of mathematical physics, South Ural State University, Chelyabinsk, Russia, hudyakov74@gmail.com

Received September 7, 2016

УДК 517.9

DOI: $10.14529 /$ jcem 160308

\section{О МАТЕМАТИЧЕСКОМ МОДЕЛИРОВАНИИ ИЗМЕРИТЕЛЬНЫХ УСТРОЙСТВ}

Ю.В. Худяков

В статье представлена обобщенная математическая модель измерительного устройства, в основе которой лежит система леонтьевского типа - вырожденная система линейных обыкновенных дифференциальных уравнений. При этом приводятся примеры из теории дескрипторных систем, свидетельствующих о том, что и в теории автоматического управления изучаются модели, частью которых является система леонтьевского типа. В системе алгебраических уравнений обобщенной модели измерительного устройства вводится дополнительное слагаемое, обусловленное необходимостью учета не только инерционности измерительного устройства, но и помех. Представлены схемы различных измерительных устройств, математическое описание которых приводит к построению обобщенной математической модели измерительного устройства.

Ключевые слова: система леонтьевского типа, динамические измерения, дескрипторные системы, теория оптимального измерения. 


\section{Литература}

1. Шестаков, А.Л. Методы теории автоматического управления в динамических измерениях / А.Л. Шестаков. - Челябинск: Изд-во ЮУрГУ, 2013.

2. Келлер, А.В. Свойство регуляризуемости и численное решение задачи динамического измерения / А.В. Келлер, Е.И. Назарова // Вестник Южно-Уральского государственного университета. Серия: Математическое моделирование и программирование. - 2010. - № 16 (192). - С. 32-38.

3. Свиридюк, Г.А. Задача Коши для линейного сингулярного кравнения типа Соболева / Г.А. Свиридюк // Дифференциальные уравнения. - 1987. - Т. 23, № 12. C. 2169 .

4. Шестаков, А.Л. Optimal Measurement of Dynamically Distorted Signals / Shestakov A.L., Sviridyuk G.A. // Вестник Южно-Уральского государственного университета. Серия: Математическое моделирование и программирование. - 2011. № 17 (234). - C. 70-75.

5. Шестаков, А.Л. Новый подход к измерению динамически искаженных сигналов / А.Л. Шестаков, Г.А. Свиридюк // Вестник Южно-Уральского государственного университета. Серия: Математическое моделирование и программирование. 2010. - № 16 (192).- C. 116-120.

6. Белов А.А. Дескрипторные системы и задачи управления / А.П. Курдюков, А.А. Белов. - М.: Физматлит, 2015.

7. Шестаков, А.Л. Измерительный преобразователь динамических параметров с итерационным принципом восстановления сигнала / А.Л. Шестаков // Приборы и системы. Управление, контроль, диагностика. - 1992. - № 10. - С. 23.

Худяков Юрий Владимирович, аспирант, кафедра уравнений математической физики, Южно-Уральский государственный университет, Челябинск, hudyakov74@gmail.com

Поступила в редакцию 7 сентября 2016 г. 